\title{
Risk stratification for children with a solitary functioning kidney
}

\author{
Sander Groen in't Woud ${ }^{1,2} \cdot$ Loes F. M. van der Zanden ${ }^{2} \cdot$ Michiel F. Schreuder $^{1}$ (D)
}

Published online: 17 June 2021

(C) IPNA 2021

In the last decade, it has become widely accepted that living with just 1 kidney may be harmful for that solitary functioning kidney (SFK) [1]. This deterioration is explained by the hyperfiltration hypothesis from Prof. Brenner [2], which states that a reduction in the number of nephrons will result in glomerular hyperfiltration in the remaining nephrons. This hyperfiltration starts a vicious cycle of glomerular hypertension, hypertrophy, and injury, which results in systemic hypertension, albuminuria, and glomerulosclerosis with a further reduction in nephron numbers.

Kidney donation is the most common cause of living with an SFK, and even though the absolute risk after kidney donation is limited, the risk for kidney failure is indeed increased [3]. However, not every kidney donor has the same risk for kidney failure. To assist in estimating an individual's risk for kidney failure after kidney donation, online calculators are available. These calculators take into account risk factors for kidney failure such as age, sex, race, obesity, and diabetes.

Children may present with an SFK as a consequence of a congenital non-functioning kidney or after nephrectomy, for instance due to malignancy. Being born with an SFK exposes glomeruli to a much longer period of hyperfiltration, and has been associated with kidney injury starting in childhood [4] and a higher risk of kidney failure later in life than after kidney donation [5]. Unfortunately, risk stratification within the group of SFK patients is not yet possible, as factors that differentiate between high and low risk groups need to be better established and the prediction model that was developed in a single study should be improved and confirmed extensively

Michiel F. Schreuder

michiel.schreuder@radboudumc.nl

1 Department of Pediatric Nephrology, 804, Radboud University Medical Center, Radboud Institute for Molecular Life Sciences, Amalia Children's Hospital, PO Box 9101, 6500, HB Nijmegen, The Netherlands

2 Department for Health Evidence, Radboud University Medical Center, Radboud Institute for Health Sciences, Nijmegen, The Netherlands
[6]. With the increasing interest in the subject, however, and the increase in size of the cohorts described, it is to be expected that such a good prediction model and a risk calculator may be developed in the coming years.

\section{Risk stratification}

In recent years, the issue of risk stratification for kidney injury in the follow-up of children with an SFK has been addressed by several authors. Similar to risk factors for chronic kidney disease (CKD) [7], such risk factors can be grouped into four categories: genetic factors (risk alleles), perinatal factors (e.g., low birth weight and premature birth), additional kidney or urinary tract abnormalities (such as vesico-ureteral reflux or the absence of kidney hypertrophy), and additional hits to the kidney (e.g., urinary tract infections (UTIs) or obesity) (Table 1). In addition to these risk factors, the degree and period of hyperfiltration, and thereby the age of the patient, plays an important role.

Patient characteristics such as sex and ethnicity could be involved. Most studies showed no association between sex and risk for kidney injury in SFK patients [4, 6, 8-12]. One notable exception is the study by Alfandary et al. in which male adolescents with SFK had a threefold higher risk of kidney injury compared to female patients [11].

In the current edition of this journal, Matsell et al. have identified that the subtype of congenital SFK may also be a risk factor for kidney injury, with a higher risk in patients with unilateral renal agenesis (URA) compared to children with a multicystic dysplastic kidney (MCDK) [20]. This is in line with the previous report from Sanna-Cherchi et al., who showed that the chance of needing dialysis at the age of 30 years was higher for patients with URA $(\sim 40 \%)$ compared with MCDK ( 20\%) [5]. Previous studies have also suggested that the risk for kidney injury is higher in patients with acquired than congenital SFK [19]. Both findings strengthen the hypothesis that the cause of SFK is an important determinant of the risk for kidney injury. 
Table 1 Potential risk factors for kidney injury in children with SFK

\begin{tabular}{lll}
\hline Risk factor & Magnitude & References \\
\hline Patient characteristics & & \\
$\quad$ Male sex & $0.8-4.4$ & {$[4,6,8-12]$} \\
Ethnicity & $\mathrm{n} / \mathrm{a}$ & $\mathrm{n} / \mathrm{a}$ \\
Duration of hyperfiltration & & \\
$\quad$ Older age (per year) & 1.1 & {$[4,9,13-18]$} \\
Cause of SFK & & \\
Acquired vs. congenital & $\mathrm{n} / \mathrm{a}$ & {$[19]$} \\
SFK & & \\
$\quad$ URA vs. MCDK & $2.1-2.7$ & {$[5,6,20]$} \\
Genetic factors & & \\
Risk alleles & $\mathrm{n} / \mathrm{a}$ & $\mathrm{n} / \mathrm{a}$ \\
Perinatal factors & & \\
Premature birth & 2.0 & {$[6]$} \\
Low birth weight & $2.1-2.7$ & {$[4,6]$} \\
Additional kidney or urinary tract abnormalities \\
Smaller SFK size (per SDS) & 1.1 & {$[4,6,11,12,17,21,22]$} \\
Additional CAKUT & $1.7-13$ & {$[4-6,11,12,17,20,23-26]$} \\
Additional hits to the kidney & & \\
Nephrotoxic drug use & $\mathrm{n} / \mathrm{a}$ & $\mathrm{n} / \mathrm{a}$ \\
Urinary tract infections & $1.6-6.7$ & {$[4,6,12,26]$} \\
Obesity & $1.4-15$ & {$[10-12,23,24,27]$} \\
Smoking & 1.5 & {$[11,23,27]$} \\
Diabetes & 4.4 & {$[18,28,29]$} \\
Hypertension & $\mathrm{n} / \mathrm{a}$ & {$[17,18,28,29]$} \\
Cardiovascular disease & 5.6 & {$[18]$} \\
Pregnancy & 2.4 & {$[30,31]$} \\
\hline
\end{tabular}

$n / a$, not available

\section{Extent of glomerular hyperfiltration}

Both the duration and timing of hyperfiltration play an important role in the risk of kidney injury. A longer period of hyperfiltration increases the chance of developing kidney injury in diabetic nephropathy, a well-known cause of hyperfiltration injury, where the duration of diabetes is associated with the risk of developing albuminuria [32]. In addition, older age has been shown to increase the proportion of SFK patients who develop hypertension [4], albuminuria [4, 13-15], and/or abnormal kidney function [16, 17]. The impact of timing has been shown by the fact that the degree of glomerular hyperfiltration was twice as high after early kidney mass reduction when compared to nephrectomy in adulthood $[1,33]$. Thus, early kidney mass reduction may increase the risk of kidney injury. During adolescence, kidney function is well known to decline at an increased speed, as has been described in patients with kidney hypodysplasia [34] or with an SFK $[4,23]$, further increasing the effect of timing (kidney mass reduction before or after puberty) on the risk of kidney injury. The kidney function decline during puberty may be explained by the rapid growth with the subsequent metabolic demand on the kidney, which the SFK is not able to deliver without a relevant change in glomerular hemodynamics. This increase in glomerular hyperfiltration, and potentially in glomerular hypertension, will lead to more glomerular injury with subsequent albuminuria. Another explanation may be that the increased demand on the kidney unveils the influence of dysplastic nephrons, in line with the findings in patients with hypodysplasia [34]. The latter may also be an explanation for the differences found between URA and MCDK by Matsell et al. [20]. Cause, timing, and duration of the renal mass reduction with subsequent hyperfiltration are all factors that should therefore be considered in the risk stratification.

\section{Genetic factors}

Genetic factors contributing to kidney injury in patients with SFK are likely to be risk alleles that, in contrast to highly penetrant disease-causing mutations, are associated with a relatively small increased risk of disease only. In a large meta-analysis of genome-wide association studies of estimated glomerular filtration rate (eGFR) in the general population, 264 loci associated with kidney function were identified [35]. When a selection of 147 of these single nucleotide polymorphisms (SNPs) was combined to calculate genetic risk scores, these scores proved to be associated with an increased risk of CKD and hypertension [35]. Although it is unlikely that similar-sized cohorts of SFK patients will be composed, smaller studies may also identify variants with prognostic value, as illustrated by the results of cohorts of patients with obstructive uropathies suggesting that variants in angiotensin converting enzyme (ACE2), angiotensin II type 2 receptor (AGTR2), and cadherin $12(C D H 12)$ are associated with the development of kidney injury [36, 37]. Interestingly, the variants in ACE2, AGTR2, and $C D H 12$ were not among the 147 SNPs used to calculate genetic risk scores for signs of kidney injury in the general population. This indicates that risk alleles for kidney injury may differ between patients with congenital anomalies of the kidney and urinary tract (CAKUT) and healthy individuals and that the search for additional risk alleles in CAKUT patients may benefit from a hypothesis-free approach.

\section{Perinatal factors}

In humans, nephrons are formed until approximately 36 weeks of pregnancy [38]. As a consequence, nephron formation may not be complete in infants born prematurely, and continued nephron development with signs of abnormal morphology has been found in preterm neonates [39]. The interindividual differences in kidney development that were observed in this study suggested that early (during active nephrogenesis) postnatal exposure to an inflammatory environment [40] or nephrotoxins may play an additional role. 
Despite the knowledge that nephrotoxic drugs such as gentamicin or indomethacin can have disrupting effects on kidney development, they are frequently used in neonatal intensive care units [41, 42]. Use of nephrotoxic drugs in premature infants with SFK may have even more detrimental effects and could pose a risk factor for kidney injury in these patients. Low birth weight $(<2500 \mathrm{~g})$ is associated with low nephron numbers [43], and was associated with a risk of kidney injury twice that of children with a normal birth weight in patients with SFK $[4,6]$. Prematurity and low birth weight could explain some of the differences in kidney function in children with SFK, and should be considered in risk stratification.

\section{Additional congenital anomalies of the kidney and urinary tract}

In a normal cSFK, compensatory growth is expected to start before birth and continue throughout childhood [12, 21, 44, 45]. Before birth, this growth can comprise both hyperplasia (increase in cell number) and hypertrophy (increase in cell size) [46]. The evidence that the absence of compensatory growth is associated with the risk of kidney injury is convincing. Several studies have found that larger SFK size, especially when present at birth, was associated with a lower risk of kidney injury $[4,6,11,12,17,21,22]$ suggesting that a responsive mechanism triggering hyperplasia is very important in dealing with kidney mass reduction. The evidence supporting an association between additional CAKUT of the SFK and kidney injury is also strong, with hazard ratios varying between 1.7 and 13, which is in line with the results reported by Dr. Matsell and colleagues [4-6, 11, 12, 17, 20, 23-26]. The association of additional CAKUT in the SFK with kidney injury may be explained by the fact that these patients are more prone to recurrent UTIs or other events that further decrease the number of nephrons.

\section{Additional hits}

In the situation of a reduced nephron number, other exposures that hurt the kidney or increase the demand on the kidney are likely to increase the risk of kidney injury. Such an increased risk has been identified repeatedly for recurrent UTIs $[4,6$, 12]. Modifiable risk factors, such as obesity, smoking, or diabetes, should be avoided as much as possible because of their associations with hypertension, albuminuria, and kidney function deterioration [11, 23, 24, 27]. For diabetes, hypertension, and cardiovascular disease, a direct relation with faster development of CKD was shown in patients with SFK [18, 28, 29]. Pregnancy is a period of additional demand on the SFK, which results in a risk for gestational hypertension and preeclampsia that is more than twice that of women with two kidneys [30, 31]. Therefore, careful monitoring of women with an SFK is necessary during pregnancy.
Previously, participation in contact sport has been advised against because of potential kidney trauma to the SFK with potentially devastating consequences. The extremely low incidence of kidney injury caused by sports participation, however, has led to a revision of these guidelines. The potential benefits of sports participation are highly likely to surpass the risks [47].

\section{Clinical implications}

The interesting results reported by Matsell et al. provide another step towards further personalizing the care for patients with an SFK [20]. Large cohorts of SFK patients will allow for the development of prediction models that can be used to stratify patients into risk categories. The recently published prediction model developed by Poggiali et al. [6] is an excellent example of what such a model could bring. In its current form, however, the additive value of this prediction model is limited, since the high-risk group is mainly determined by occurrence of multiple UTIs. This information is not yet available in early life and would only allow for adjustment of the follow-up strategy after a second or third UTI has taken place. The same is likely to be done in regular care, since most clinicians would increase follow-up frequency and/or consider treatment in a child with SFK and recurrent UTIs. A prediction model would be especially helpful if it would contain only predictive factors occurring early in life, for instance within the first year, so a tailored follow-up strategy can be initiated from then on. Furthermore, the current model was based on only 18 events in 162 patients. In prediction modelling, a minimum of 10 events per variable (EPV) is usually advised and an EPV $\geq 20$ has been advocated to obtain more reliable predictions [48]. Collaborative efforts of research groups will be needed to create and validate prediction models that are applicable in different centers and healthcare settings. If such a prediction model is established, it will likely improve the current recommendations for the follow-up of SFK patients [1, 49], allowing for better and more cost-efficient clinical management. In addition, identification of SFK patients with a high risk of kidney injury facilitates targeted research in these groups, for example regarding innovative biomarkers of kidney injury or future therapies slowing down or even preventing the progression of kidney injury.

Funding MFS is supported by a Vidi (91716454) and LvdZ by a Veni (91618036) grant from the Dutch Research Council (NWO).

\section{References}

1. Schreuder MF (2018) Life with one kidney. Pediatr Nephrol 33: 595-604

2. Brenner BM, Lawler EV, Mackenzie HS (1996) The hyperfiltration theory: a paradigm shift in nephrology. Kidney Int 49:1774-1777 
3. Matas AJ, Rule AD (2021) Risk of kidney disease after living kidney donation. Nat Rev Nephrol. https://doi.org/10.1038/ s41581-021-00407-5

4. Westland R, Kurvers RA, van Wijk JA, Schreuder MF (2013) Risk factors for renal injury in children with a solitary functioning kidney. Pediatrics 131:e478-e485

5. Sanna-Cherchi S, Ravani P, Corbani V, Parodi S, Haupt R, Piaggio G, Innocenti ML, Somenzi D, Trivelli A, Caridi G, Izzi C, Scolari F, Mattioli G, Allegri L, Ghiggeri GM (2009) Renal outcome in patients with congenital anomalies of the kidney and urinary tract. Kidney Int 76:528-533

6. Poggiali IV, Simoes ESAC, Vasconcelos MA, Dias CS, Gomes IR, Carvalho RA, Oliveira MCL, Pinheiro SV, Mak RH, Oliveira EA (2019) A clinical predictive model of renal injury in children with congenital solitary functioning kidney. Pediatr Nephrol 34:465474

7. Stern-Zimmer M, Calderon-Margalit R, Skorecki K, Vivante A (2020) Childhood risk factors for adulthood chronic kidney disease. Pediatr Nephrol 36:1387-1396

8. Westland R, Schreuder MF (2014) Gender differences in solitary functioning kidney: do they affect renal outcome? Pediatr Nephrol 29:2243-2244

9. Kim S, Chang Y, Lee YR, Jung HS, Hyun YY, Lee KB, Joo KJ, Yun KE, Shin H, Ryu S (2019) Solitary kidney and risk of chronic kidney disease. Eur J Epidemiol 34:879-888

10. La Scola C, Marra G, Ammenti A, Pasini A, Taroni F, Bertulli C, Morello W, Ceccoli M, Mencarelli F, Guarino S, Puccio G, Montini G (2020) Born with a solitary kidney: at risk of hypertension. Pediatr Nephrol 35:1483-1490

11. Alfandary H, Haskin O, Goldberg O, Dagan A, Borovitz Y, Levi S, Davidovits M, Erlich T, Landau D, Pleniceanu O (2021) Is the prognosis of congenital single functioning kidney benign?A population-based study. Pediatr Nephrol. https://doi.org/10.1007/ s00467-021-04980-6

12. La Scola C, Ammenti A, Puccio G, Lega MV, De Mutiis C, Guiducci C, De Petris L, Perretta R, Venturoli V, Vergine G, Zucchini A, Montini G (2016) Congenital solitary kidney in children: size matters. J Urol 196:1250-1256

13. Wikstad I, Celsi G, Larsson L, Herin P, Aperia A (1988) Kidney function in adults born with unilateral renal agenesis or nephrectomized in childhood. Pediatr Nephrol 2:177-182

14. Shirzai A, Yildiz N, Biyikli N, Ustunsoy S, Benzer M, Alpay H (2014) Is microalbuminuria a risk factor for hypertension in children with solitary kidney? Pediatr Nephrol 29:283-288

15. Siomou E, Giapros V, Papadopoulou F, Pavlou M, Fotopoulos A, Siamopoulou A (2014) Growth and function in childhood of a normal solitary kidney from birth or from early infancy. Pediatr Nephrol 29:249-256

16. Cozzi DA, Ceccanti S, Cozzi F (2018) Renal function up to the 5th decade of life after nephrectomy in childhood: a literature review. Nephrology (Carlton) 23:397-404

17. Grapin M, Gaillard F, Biebuyck N, Ould-Rabah M, Hennequin C, Berthaud R, Dorval G, Blanc T, Hourmant M, Kamar N, Rostaing L, Couzi L, Garcelon N, Prie D, Boyer O, Bienaime F (2021) The spectrum of kidney function alterations in adolescents with a solitary functioning kidney. Pediatr Nephrol. https://doi.org/10.1007/ s00467-021-05074-Z

18. Zhang W-J, Wang Z-Y, Zhou W-X, Yang N-Q, Wang Y, Tang Y, Zhou X-C, Dao J-C, Ma Y-R, He Y-P, Wang X-L, Wang W-G, Yang L (2020) Identifying risk factors for chronic kidney disease stage 3 in adults with acquired solitary kidney from unilateral nephrectomy: a retrospective cohort study. BMC Nephrol 21:397

19. Abou Jaoude P, Dubourg L, Bacchetta J, Berthiller J, Ranchin B, Cochat P (2011) Congenital versus acquired solitary kidney: is the difference relevant? Nephrol Dial Transplant 26:2188-2194
20. Matsell DG, Bao C, Po White T, Chan E, Matsell E, Cojocaru D, Catapang M, Pediatric Nephrology Clinical Pathway Development Team (2021) Outcomes of solitary functioning kidneys-renal agenesis is different than multicystic dysplastic kidney disease. Pediatr Nephrol. https://doi.org/10.1007/s00467-021-05064-1

21. Marzuillo P, Guarino S, Grandone A, Di Somma A, Diplomatico M, Rambaldi PF, Decimo F, Miraglia Del Giudice E, La Manna A, Polito C (2019) Congenital solitary kidney size at birth could predict reduced eGFR levels later in life. J Perinatol 39:129-134

22. Dursun H, Bayazit AK, Cengiz N, Seydaoglu G, Buyukcelik M, Soran M, Noyan A, Anarat A (2007) Ambulatory blood pressure monitoring and renal functions in children with a solitary kidney. Pediatr Nephrol 22:559-564

23. Marzuillo P, Guarino S, Di Sessa A, Rambaldi PF, Reginelli A, Vacca G, Cappabianca S, Capalbo D, Esposito T, De Luca PC, Arienzo MR, Cirillo G, La Manna A, Miraglia Del Giudice E, Polito C (2020) Congenital solitary kidney from birth to adulthood. J Urol 205:1466-1475. https://doi.org/10.1097/JU. 000000000001524

24. Urisarri A, Gil M, Mandia N, Aldamiz-Echevarria L, Iria R, Gonzalez-Lamuno D, Couce ML (2018) Retrospective study to identify risk factors for chronic kidney disease in children with congenital solitary functioning kidney detected by neonatal renal ultrasound screening. Medicine (Baltimore) 97:e11819

25. Akl K (2011) The anomalies associated with congenital solitary functioning kidney in children. Saudi J Kidney Dis Transpl 22: $67-71$

26. Seeman T, Patzer L, John U, Dusek J, Vondrak K, Janda J, Misselwitz J (2006) Blood pressure, renal function, and proteinuria in children with unilateral renal agenesis. Kidney Blood Press Res 29:210-215

27. Gonzalez E, Gutierrez E, Morales E, Hernandez E, Andres A, Bello I, Diaz-Gonzalez R, Leiva O, Praga M (2005) Factors influencing the progression of renal damage in patients with unilateral renal agenesis and remnant kidney. Kidney Int 68:263-270

28. Silveiro SP, da Costa LA, Beck MO, Gross JL (1998) Urinary albumin excretion rate and glomerular filtration rate in singlekidney type 2 diabetic patients. Diabetes Care 21:1521-1524

29. Gabriele MM, Koch Nogueira PC (2019) Management of hypertension in CAKUT: protective factor for CKD. Front Pediatr 7:222

30. Garg AX, Nevis IF, McArthur E, Sontrop JM, Koval JJ, Lam NN, Hildebrand AM, Reese PP, Storsley L, Gill JS, Segev DL, Habbous S, Bugeja A, Knoll GA, Dipchand C, Monroy-Cuadros M, Lentine KL; Donor Nephrectomy Outcomes Research (DONOR) Network (2015) Gestational hypertension and preeclampsia in living kidney donors. N Engl J Med 372:124-133

31. Kendrick J, Holmen J, You Z, Smits G, Chonchol M (2017) Association of unilateral renal agenesis with adverse outcomes in pregnancy: a matched cohort study. Am J Kidney Dis 70:506-511

32. Liang S, Cai GY, Chen XM (2017) Clinical and pathological factors associated with progression of diabetic nephropathy. Nephrology 22:14-19

33. Larsson L, Aperia A, Wilton P (1980) Effect of normal development on compensatory renal growth. Kidney Int 18:29-35

34. Ardissino G, Testa S, Dacco V, Paglialonga F, Vigano S, FeliceCivitillo C, Battaglino F, Bettinelli A, Bordugo A, Cecchetti V, De Pascale S, La Manna A, Li Volti S, Maringhini S, Montini G, Pennesi M, Peratoner L (2012) Puberty is associated with increased deterioration of renal function in patients with CKD: data from the ItalKid Project. Arch Dis Child 97:885-888

35. Wuttke M, Li Y, Li M, Sieber KB, Feitosa MF, Gorski M, Tin A, Wang L, Chu AY, Hoppmann A, Kirsten H, Giri A, Chai J-F, Sveinbjornsson G, Tayo BO, Nutile T, Fuchsberger C, Marten J, Cocca M, Ghasemi S, Xu Y, Horn K, Noce D, van der Most PJ, Sedaghat S, Yu Z, Akiyama M, Afaq S, Ahluwalia TS, Almgren P, Amin N, Arnlov J, Bakker SJL, Bansal N, Baptista D, Bergmann S, 
Biggs ML, Biino G, Boehnke M, Boerwinkle E, Boissel M, Bottinger EP, Boutin TS, Brenner H, Brumat M, Burkhardt R, Butterworth AS, Campana E, Campbell A, Campbell H, Canouil M, Carroll RJ, Catamo E, Chambers JC, Chee M-L, Chee M-L, Chen X, Cheng C-Y, Cheng Y, Christensen K, Cifkova R, Ciullo M, Concas MP, Cook JP, Coresh J, Corre T, Sala CF, Cusi D, Danesh J, Daw EW, de Borst MH, De Grandi A, de Mutsert R, de Vries APJ, Degenhardt F, Delgado G, Demirkan A, Di Angelantonio E, Dittrich K, Divers J, Dorajoo R, Eckardt K-U, Ehret G, Elliott P, Endlich K, Evans MK, Felix JF, Foo VHX, Franco OH, Franke A, Freedman BI, Freitag-Wolf S, Friedlander Y, Froguel P, Gansevoort RT, Gao H, Gasparini P, Gaziano JM, Giedraitis V, Gieger C, Girotto G, Giulianini F, Gogele M, Gordon SD, Gudbjartsson DF, Gudnason V, Haller T, Hamet P, Harris TB, Hartman CA, Hayward C, Hellwege JN, Heng C-K, Hicks AA, Hofer E, Huang W, Hutri-Kahonen N, Hwang S-J, Ikram MA, Indridason OS, Ingelsson E, Ising M, Jaddoe VWV, Jakobsdottir J, Jonas JB, Joshi PK, Josyula NS, Jung B, Kahonen M, Kamatani Y, Kammerer CM, Kanai M, Kastarinen M, Kerr SM, Khor C-C, Kiess W, Kleber ME, Koenig W, Kooner JS, Korner A, Kovacs P, Kraja AT, Krajcoviechova A, Kramer H, Kramer BK, Kronenberg F, Kubo M, Kuhnel B, Kuokkanen M, Kuusisto J, La Bianca M, Laakso M, Lange LA, Langefeld CD, Lee JJ-M, Lehne B, Lehtimaki T, Lieb W, Lifelines Cohort S, Lim S-C, Lind L, Lindgren CM, Liu J, Liu J, Loeffler M, Loos RJF, Lucae S, Lukas MA, Lyytikainen L-P, Magi R, Magnusson PKE, Mahajan A, Martin NG, Martins J, Marz W, Mascalzoni D, Matsuda K, Meisinger C, Meitinger T, Melander O, Metspalu A, Mikaelsdottir EK, Milaneschi Y, Miliku K, Mishra PP, Program VAMV, Mohlke KL, Mononen N, Montgomery GW, MookKanamori DO, Mychaleckyj JC, Nadkarni GN, Nalls MA, Nauck M, Nikus K, Ning B, Nolte IM, Noordam R, O'Connell J, O'Donoghue ML, Olafsson I, Oldehinkel AJ, Orho-Melander M, Ouwehand WH, Padmanabhan S, Palmer ND, Palsson R, Penninx BWJH, Perls T, Perola M, Pirastu M, Pirastu N, Pistis G, Podgornaia AI, Polasek O, Ponte B, Porteous DJ, Poulain T, Pramstaller PP, Preuss MH, Prins BP, Province MA, Rabelink TJ, Raffield LM, Raitakari OT, Reilly DF, Rettig R, Rheinberger M, Rice KM, Ridker PM, Rivadeneira F, Rizzi F, Roberts DJ, Robino A, Rossing P, Rudan I, Rueedi R, Ruggiero D, Ryan KA, Saba Y, Sabanayagam C, Salomaa V, Salvi E, Saum K-U, Schmidt H, Schmidt R, Schottker B, Schulz C-A, Schupf N, Shaffer CM, Shi Y, Smith AV, Smith BH, Soranzo N, Spracklen CN, Strauch K, Stringham HM, Stumvoll M, Svensson PO, Szymczak S, Tai ES, Tajuddin SM, Tan NYQ, Taylor KD, Teren A, Tham Y-C, Thiery J, Thio CHL, Thomsen H, Thorleifsson G, Toniolo D, Tonjes A, Tremblay J, Tzoulaki I, Uitterlinden AG, Vaccargiu S, van Dam RM, van der Harst P, van Duijn CM, Velez Edward DR, Verweij N, Vogelezang S, Volker U, Vollenweider P, Waeber G, Waldenberger M, Wallentin L, Wang YX, Wang C, Waterworth DM, Bin Wei W, White H, Whitfield JB, Wild SH, Wilson JF, Wojczynski MK, Wong C, Wong T-Y, Xu L, Yang Q, Yasuda M, Yerges-Armstrong LM, Zhang W, Zonderman AB, Rotter JI, Bochud M, Psaty BM, Vitart V, Wilson JG, Dehghan A, Parsa A, Chasman DI, Ho K, Morris AP, Devuyst O, Akilesh S, Pendergrass SA, Sim X, Boger CA, Okada Y, Edwards TL, Snieder H, Stefansson K, Hung AM, Heid IM, Scholz M, Teumer A, Kottgen A, Pattaro C (2019) A catalog of genetic loci associated with kidney function from analyses of a million individuals. Nat Genet 51:957-972
36. Laksmi NK, Narasimhan KL, Khullar M, Madhu K, Kaur B, Balpinder K, Ahuja M, Monica A, Mahajan JK, Kumar MJ, Mittal BR, Rai MB, Bhattacharya A, Anish B, Medhi B, Bikash $M$ (2010) Association of angiotensin converting enzyme and angiotensin type 2 receptor gene polymorphisms with renal damage in posterior urethral valves. J Pediatr Urol 6:560-566

37. van der Zanden LFM, van Rooij IALM, Quaedackers JSLT, Nijman RJM, Steffens M, de Wall LLL, Bongers EMHF, Schaefer F, Kirchner M, Behnisch R, Bayazit AK, Caliskan S, Obrycki L, Montini G, Duzova A, Wuttke M, Jennings R, Hanley NA, Milmoe NJ, Winyard PJD, Renkema KY, Schreuder MF, Roeleveld N, Feitz WFJ (2021) CDH12 as a candidate gene for kidney injury in posterior urethral valve cases: a genome-wide association study among patients with obstructive uropathies. Eur Urol Open Sci 28:26-35

38. Hinchliffe SA, Sargent PH, Howard CV, Chan YF, van Velzen D (1991) Human intrauterine renal growth expressed in absolute number of glomeruli assessed by the disector method and Cavalieri principle. Lab Investig 64:777-784

39. Black MJ, Sutherland MR, Gubhaju L, Kent AL, Dahlstrom JE, Moore L (2013) When birth comes early: effects on nephrogenesis. Nephrology (Carlton, Vic ) 18:180-182

40. Hoogenboom LA, Wolfs T, Hutten MC, Peutz-Kootstra CJ, Schreuder MF (2021) Prematurity, perinatal inflammatory stress, and the predisposition to develop chronic kidney disease beyond oligonephropathy. Pediatr Nephrol. https://doi.org/10.1007/ s00467-020-04712-2

41. Schreuder MF, Bueters RR, Huigen MC, Russel FG, Masereeuw R, van den Heuvel LP (2011) Effect of drugs on renal development. Clin J Am Soc Nephrol 6:212-217

42. Rhone ET, Carmody JB, Swanson JR, Charlton JR (2014) Nephrotoxic medication exposure in very low birth weight infants. J Matern Fetal Neonatal Med 27:1485-1490

43. Bertram JF, Douglas-Denton RN, Diouf B, Hughson MD, Hoy WE (2011) Human nephron number: implications for health and disease. Pediatr Nephrol 26:1529-1533

44. Schreuder MF, Westland R, van Wijk JA (2009) Unilateral multicystic dysplastic kidney: a meta-analysis of observational studies on the incidence, associated urinary tract malformations and the contralateral kidney. Nephrol Dial Transplant 24:1810 1818

45. Westland R, Schreuder MF, Ket JC, van Wijk JA (2013) Unilateral renal agenesis: a systematic review on associated anomalies and renal injury. Nephrol Dial Transplant 28:1844-1855

46. Douglas-Denton R, Moritz KM, Bertram JF, Wintour EM (2002) Compensatory renal growth after unilateral nephrectomy in the ovine fetus. J Am Soc Nephrol 13:406-410

47. Grinsell MM, Butz K, Gurka MJ, Gurka KK, Norwood V (2012) Sport-related kidney injury among high school athletes. Pediatrics 130:e40-e45

48. Ogundimu EO, Altman DG, Collins GS (2016) Adequate sample size for developing prediction models is not simply related to events per variable. J Clin Epidemiol 76:175-182

49. Groen In't Woud S, Westland R, Feitz WF, Roeleveld N, Van Wijk JA, Van der Zanden LF, Schreuder MF (2021) Clinical management of children with a congenital solitary functioning kidney: overview and recommendations. Eur Urol Open Sci 25:11-20

Publisher's note Springer Nature remains neutral with regard to jurisdictional claims in published maps and institutional affiliations. 